\title{
Iron Metabolism in the Anaemia of Chronic Renal Failure. Effects of Dialysis and of Parenteral Iron
}

\author{
R. A. CARTER,* M.B., M.R.C.P., M.C.PATH. ; J. B. HAWKINS, $†$ M.B., M.R.C.P., D.C.H. \\ B. H. B. ROBINSON, $\ddagger$ M.A., M.B., M.R.C.P.
}

British Medical fournal, 1969, 3, 206-210

\begin{abstract}
Summary : Serial studies of iron transport in patients on $S$ maintenance dialysis showed normal or raised values in almost all subjects and a transient increase soon after the start of dialysis in three. These patients, who were seldom or never transfused, had low serum iron levels and normal iron-binding capacity with low saturation. Iron transport was substantially increased by parenteral irondextran treatment. Traser studies showed good iron utilization, with transport to the marrow rather than to the liver. In these circumstances iron therapy is safe and beneficial, and a useful rise in red cell mass was shown to result from it. The packed cell volume was found to be a valid index of red cell mass in these patients. Red cell lose in the dialysers was insufficient to account for the observed reduction in red cell survival.
\end{abstract}

\section{Introduction}

Chronic renal failure is accompanied by anaemia characteristically resistant to haematinics. This anaemia has been attributed to reduced red cell survival (Emerson and Burrows, 1949), to reduced red cell production (Chodos, 1956), or to a combination of both mechanisms (Joske et al. :956). The reduction in erythropoiesis may be attributable to lack of erythropoietin production by the kidneys (Mann et al., 1965), but probably the biochemical disturbances of severe uraemia also influence bone marrow activity. Dialysis has been followed by an initial increase in erythroid iron turnover (Kurtides et al., 1964; Mann et al., 1965), but the studies of Eschbach et al. (1967) failed to show any clear-cut effect of dialysis on iron utilization in patients who were already on maintenance dialysis. It is probably relevant that these patients were routinely transfused in order to maintain packed cell volumes above $24 \%$.

The purpose of the present study was to investigate the pattern of iron kinetics in patients treated by intermittent dialysis without transfusion. By means of an isotope of short half-life ${ }^{52} \mathrm{Fe}$, half-life 8.2 hours) serial studies of plasma iron clearance could be made in these patients to try to discern any effect of dialysis and of the administration of therapeutic doses of iron compounds. The packed cell volume is often used as a guide in the assessment of anaemia in dialysed patients. The rapid changes in plasma volume which may occur in patients treated by dialysis, however, cast doubt on the validity of using the packed cell volume as a guide to erythropoietic adequacy. We have therefore studied the relation between red cell mass and packed cell volume at various intervals between dialysis.

\section{Clinical Data}

The details of the 15 patients studied are summarized in Table I. In each of them a Teflon-Silastic arteriovenous shunt had been inserted. They were dialysed twice or thrice

* Consultant Pathologist.
+ Sheldon Research Fellow.

† Sheldon Research Fell

Renal Unit and Department of Patho'ozy, Eat Bimingham Hospital, Birm:ngham 9. weekly by means of the two-layered low-volume Kiil dialyser with PT150 cuprophane membranes for a minimum total of 28 hours per week. A few patients had previously been dialysed for a short period (one to three months) on coil dialysers which had been primed with blood. The Kiil dialysers were primed with saline, and blood transfusion was given only when severe symptoms of anaemia or blood loss necessitated it. None of the patients, however, required transfusion during the period of the study. Some were investigated at the time of admission to the dialysis programme or as soon as possible thereafter. These patients were reinvestigated at intervals to assess the effect of dialysis on iron transport. Another group of patients were investigated before, during, and after a period during which parenteral iron-dextran (Imferon) had been injected into the venous line at the end of each dialysis; $2 \mathrm{ml}$. of this, equivalent to $100 \mathrm{mg}$. of elemental iron, was given on each occasion.

\begin{tabular}{|c|c|c|c|c|c|c|}
\hline $\begin{array}{l}\text { Case } \\
\text { No. }\end{array}$ & $\begin{array}{l}\text { Sex } \\
\text { and } \\
\text { Age }\end{array}$ & Diagnosis & $\begin{array}{l}\text { Mean Value } \\
\text { of Blood } \\
\text { Urea at } \\
\text { Start of } \\
\text { Each Dialysis } \\
\text { (mg./100 ml.) }\end{array}$ & $\begin{array}{c}\text { Serum } \\
\text { Iron } \\
\text { before } \\
\text { Study } \\
(\mu \mathrm{g} . / \\
100 \mathrm{ml} .)\end{array}$ & $\begin{array}{c}\text { Duration } \\
\text { on } \\
\text { Dialysis } \\
\text { at } \\
\text { First } \\
\text { Study }\end{array}$ & $\begin{array}{l}\text { Transfusion } \\
\text { before } \\
\text { Study }\end{array}$ \\
\hline 1 & F 21 & GMN & 170 & 20 & 9 months & $\begin{array}{l}\text { Frequent till } 3 \\
\text { months before } \\
\text { study. Only } \\
\text { once since } \\
\text { then }\end{array}$ \\
\hline 2 & $\begin{array}{ll}\mathrm{F} & 34 \\
\mathrm{M} & 37\end{array}$ & $\begin{array}{l}\text { CPN } \\
\text { GMN }\end{array}$ & $\begin{array}{l}120 \\
115\end{array}$ & $\begin{array}{l}69 \\
82\end{array}$ & $\begin{array}{l}7 \text { weeks } \\
\text { Nil }\end{array}$ & $\begin{array}{l}\text { One unit only } \\
\text { None }\end{array}$ \\
\hline 4 & $M 55$ & GMN & 150 & 82 & 12 months & $\begin{array}{l}\text { Frequent till } 3 \\
\text { months } \\
\text { before. None } \\
\text { since }\end{array}$ \\
\hline 5 & M 20 & $\begin{array}{l}\text { Alport's } \\
\text { syndrome }\end{array}$ & 120 & 46 & 1 day & $\begin{array}{l}4 \text { units, } 4 \text { weeks } \\
\text { before }\end{array}$ \\
\hline 6 & M 47 & $\begin{array}{l}\text { Polycystic } \\
\text { kidneys }\end{array}$ & 170 & 60 & 7 months & None \\
\hline 7 & F 30 & CPN & 105 & 60 & 2 weeks & $\begin{array}{l}4 \text { pints }(2 \cdot 3 \\
\text { litres) one } \\
\text { month before }\end{array}$ \\
\hline $\begin{array}{r}8 \\
9 \\
10\end{array}$ & $\begin{array}{ll}\mathrm{F} & 30 \\
\mathrm{~F} & 27 \\
\mathrm{M} & 47\end{array}$ & $\begin{array}{l}\text { CPN } \\
\text { CPN } \\
\text { Analgesic }\end{array}$ & $\begin{array}{r}80 \\
110 \\
100\end{array}$ & $\begin{array}{l}64 \\
50 \\
42\end{array}$ & $\begin{array}{l}6 \text { months } \\
7 \text { days } \\
4 \text { weeks }\end{array}$ & $\begin{array}{l}\text { None } \\
\text { None } \\
\text { None }\end{array}$ \\
\hline $\begin{array}{l}11 \\
12 \\
13\end{array}$ & $\begin{array}{ll}M & 43 \\
M & 35 \\
M & 49\end{array}$ & $\begin{array}{l}\text { nephropathy } \\
\text { GMN } \\
\text { CPN } \\
\text { GMN }\end{array}$ & $\begin{array}{l}100 \\
110 \\
150\end{array}$ & $\begin{array}{l}43 \\
45 \\
70\end{array}$ & $\begin{array}{l}4 \text { Nil } \\
11 \text { months } \\
11 \text { months }\end{array}$ & $\begin{array}{l}\text { None } \\
\text { None } \\
\text { Twice (two }\end{array}$ \\
\hline 14 & M 31 & $\begin{array}{c}\text { Polycystic } \\
\text { kidneys }\end{array}$ & 100 & 52 & 3 months & None \\
\hline 15 & M 30 & $\begin{array}{c}\text { Malignant } \\
\text { hypertension }\end{array}$ & 115 & 38 & 3 weeks & None \\
\hline
\end{tabular}

GMN $=$ Glomerulonephritis. $\quad \mathrm{CPN}=$ Non-obstructive chronic pyelonephritis.

\section{Methods}

For serial studies of iron clearance and red cell mass the following procedure was adopted at each study. The patient came to the hospital at about 5 p.m. and a medication rubber insert was placed between the two limbs of the shunt followed by an injection of 2,000 units of heparin. The venous end of this medication rubber insert was used for all injections and the arterial end for all sample-taking during the study to obviate any discomfort and risk of damage to potential shunt sites.

Seventeen millilitres of blood was withdrawn into $3 \mathrm{ml}$. of acid citrate dextrose and the red cells were separated by centrifuging at 1,000 r.p.m. Five microcuries of ${ }^{2} \mathrm{Fe}$ was added 
to $10 \mathrm{ml}$. of plasma and allowed to stand for 15 minutes at room temperature; a weighed amount was then reinjected. A further weighed amount was kept as a standard. Blood samples for serum iron estimation were taken at 20,40 , and 60 minutes after reinjection. The radioactivity of the samples was determined 100 minutes $^{1}$ after the last sample was taken; the results were expressed as half-clearance time and iron transport (Lajtha, 1961).

As soon as the plasma had been set to incubate with the ${ }^{52} \mathrm{Fe}$ the separated red cells were washed in $3 \%$ plasma saline (made with the surplus of the patient's own plasma), packed by centrifuging at 1,000 r.p.m., and the supernatant discarded. Enough ${ }^{86} \mathrm{RbCl}_{3}$ was added to give a final uptake of between 5 and $10 \mu \mathrm{Ci}_{1}{ }^{3}$ and the mixture was incubated at $37^{\circ} \mathrm{C}$. for 60 to 75 minutes. After incubation the cells were washed twice with plasma saline at $4^{\circ} \mathrm{C}$. and resuspended in this. A weighed amount was reinjected and a further amount retained as standard. A final sample was withdrawn 10 to 15 minutes after reinjection for estimation of red cell mass. This and the standard were counted in a well crystal counter four days later. The delay allowed complete decay of ${ }^{52} \mathrm{Fe}$ while resulting in only moderate loss of rubidium activity (half-life 14 days).

Long-term studies with ${ }^{59} \mathrm{Fe}$ and ${ }^{51} \mathrm{Cr}$ were carried out in the usual manner (Lajtha, 1961). Serum iron and ironbinding capacity were estimated on the AutoAnalyzer with Tripyridyl and by a manual method using Bathophenanthroline. Both methods were often used on the same samples, and close agreement was obtained. Conventional methods were used for estimating urea, creatinine, packed cell volume, reticulocytes, and haemoglobin.

Blood loss was estimated by labelling the patients' cells with ${ }^{51} \mathrm{Cr}$ (Lajtha, 1961) and collecting the fluid left in the Kiil dialyser, together with the membranes and connecting lines. These were all placed into a 1-litre wide-mouthed bottle at the end of dialysis. They were counted in a large-volume scintillation counter against a standard composed of a known amount of the patient's blood, which had been taken towards the end of dialysis and diluted to a similar volume in water and in an identical type of bottle.

\section{Results}

\section{Packed Cell Volume as Index of Red Cell Mass}

In patients maintained by dialysis a close correlation exists $(r=0.94$, S.E. $=0.21)$ between arterial blood haematocrit values measured at varying times between dialyses and the red cell mass (in ml./kg.) as determined by labelling cells with ${ }^{86} \mathrm{Rb}$ or ${ }^{51} \mathrm{Cr}$ (Fig. 1). The correlation was less exact before maintenance dialysis was started because of a relative expansion of plasma volume.

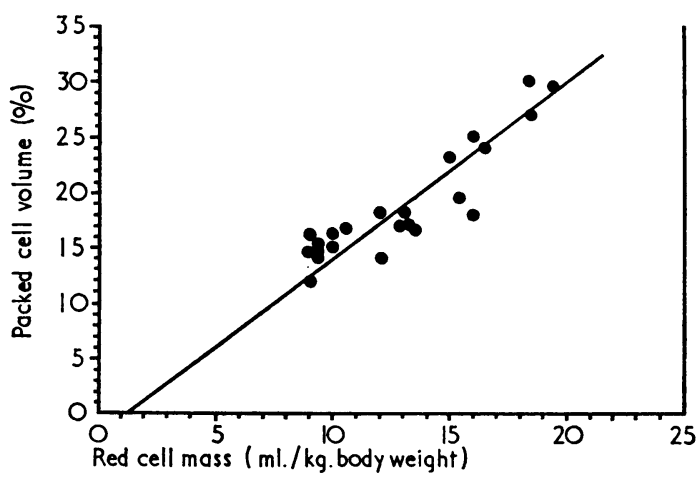

FIG. 1.-Red cell mass determinations related to arteria haematocrit reading. The correlation coefficient is 0.94 and the line is the calculated regression line, the equation of which is P.C.V. $=1.61 \times$ red cell mass (ml. $/ \mathrm{kg}$ body weight) $-2 \cdot 2$ Only patients receiving regular mainten ance dialysis are represented on the graph.

${ }^{2}$ For details see appendix concerning the use of ${ }^{52} \mathrm{Fe}$ and ${ }^{86} \mathbf{R b}$.

\section{Iron Metabolism}

In most of the group of non-transfused patients on maintenance dialysis who were studied by us the plasma iron transport was within the normal range (Fig. 2). Studies made shortly after dialysis had begun indicated that a sharp rise in iron transport might occur during the early days of the treatment, but that if so the effect would be transient (Fig. 3). After the first two months of dialysis the plasma iron transport had returned to predialysis levels. Though in most patients studied the transport was normal or raised, in some it was slightly below normal. It has not been possible to relate this difference to differences in the adequacy of dialysis as assessed by serum urea or creatinine levels.

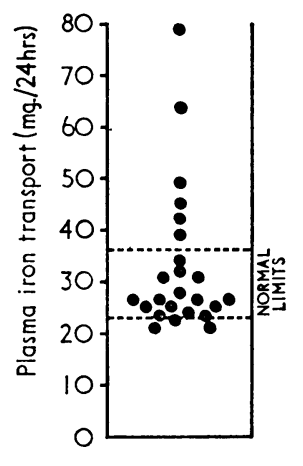

FIG. 2

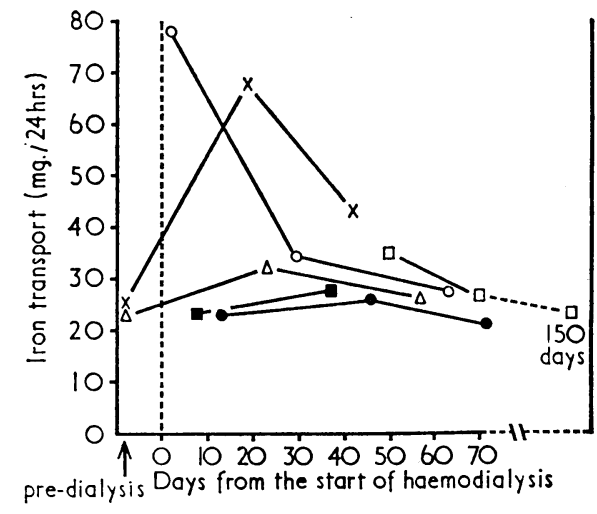

Fig. 3
FIG. 2.-Distribution of plasma iron transport values in dialysed patients not receiving iron therapy. FIG. 3.-Effect of beginning regular dialysis treatment on iron transport. O-O Case $5 ; \times 1 \times$ Case 3 ;

Plasma iron levels in these patients were nearly always low (42 to 86 , mean $60 \mu \mathrm{g}$./100 ml.) before treatment with iron, whereas the iron-binding capacity was normal (range 228 to 468 , with mean of 22 observations $=368 \mu \mathrm{g}$. $/ 100 \mathrm{ml}$. ; saturation 13 to $27 \%$, mean $18.8 \%$ ). The administration of irondextran raised the plasma iron level and produced a concomitant increase in plasma iron transport (Fig. 4), which was

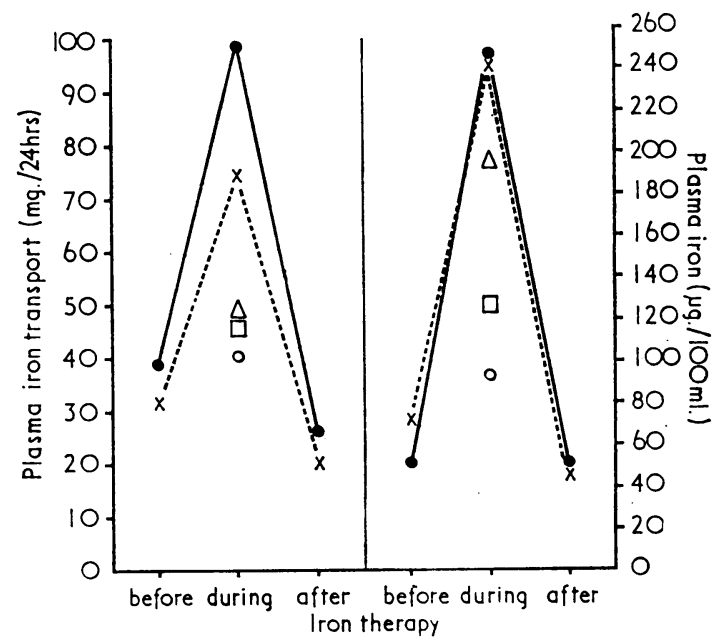

FIG. 4.-Effect of parenteral iron therapy on serum iron and iron transport in patients well established on maintenance dialysis. $\triangle \triangle$ Case $8 ; \square-\square^{\circ}$ Case $13 ; 0$

largely explained by the change in plasma iron level rather than by an abnormal variation in clearance time. Values of serum iron and iron transport fell again after the course of injections was stopped. 
Studies with ${ }^{59} \mathrm{Fe}$ in four patients showed that with or without parenteral iron therapy there was a normal pattern of accumulation of iron in the bone marrow and no abnormal accumulation in other organs. Red cell iron utilization was efficient in three of the four patients (Case $996 \%$, Case 12 $86 \%$, Case $1384 \%$, Case $567 \%$; normal 70 to $90 \%$ ). Most of those treated with parenteral iron also showed a rise in haemoglobin levels consistent with the increase in plasma iron levels and transport (Fig. 5). Nevertheless, it was only in the two patients with polycystic disease of the kidneys that the haemoglobin levels rose to nearly normal. After the administration of parenteral iron had been discontinued the plasma iron levels often fell quite rapidly ; this was followed by a fall in haemoglobin, but not necessarily in mean corpuscular haemoglobin concentration. In most patients the haemoglobin concentration did not rise above the range of 6 to $9 \mathrm{~g} . / 100 \mathrm{ml}$. despite therapy. All of these patients had normal or raised serum vitamin- $B_{12}$ levels. Where folate levels were low-as was commonly the case before dialysis was begun-folic acid was administered, but no convincing effect on erythropoiesis or haemoglobin levels was seen.

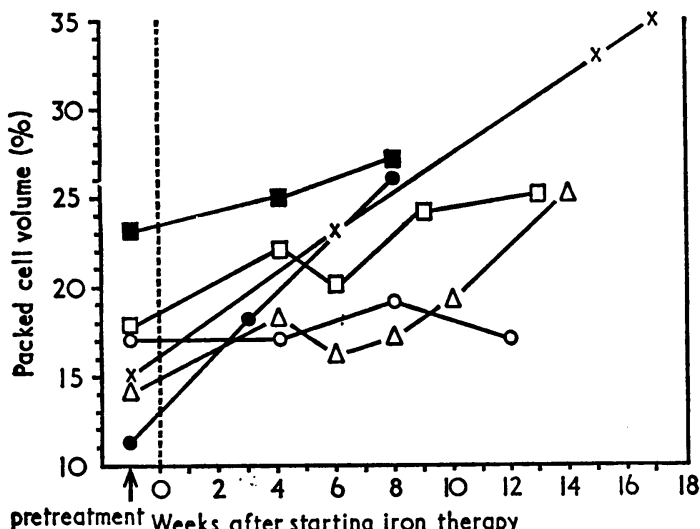

FiG. 5.-Response to parenteral Iron therapy in patients on maintenance dialyais without blood transfusions. $\triangle \longrightarrow \triangle$ Case $8 ; \square \longrightarrow$ Case $7 ; \times 1 ; \square$ Case 6 Case 12 .

\section{Red Cell Survival and Red Cell Loss in Dialyser}

Red cells were labelled with ${ }^{51} \mathrm{Cr}$ in four patients, and the results of survival studies indicated a slight to moderate reduction in red cell life in these patients. The figures obtained were: Case 252 days, Case 776 days, Case 1575 days, Case 14 90 days (normal 110 days). In all the patients the observations made virtually corresponded to a straight-line relationship between time and percentage survival. This suggests that the reduced red cell survival is due to an intrinsic defect rather than to random loss or destruction. Clear-cut evidence of reduced survival was also seen during the ${ }^{89} \mathrm{Fe}$ study on Case 5 . In the studies on Cases 12 and 9 falls in circulating red cell iron activity occurred after the seventh day, suggesting that survival was impaired, but not great enough to be conclusive. No such effect was seen in Case 13. It must be appreciated that iron utilization studies are a much less sensitive way of detecting reduced red cell survival than chromium labelling.

Some of the observed reduction in red cell survival could be explained by loss in the dialyser owing to blood remaining in the apparatus at the end of dialysis. Losses were measured as described above on six consecutive occasions in two patients who were on twice-weekly dialysis (Table II). From these it is clear that the excess turnover of red cells exceeds that due to natural destruction at normal rates by an amount which is too great to be explained by dialyser losses alone. Nor is it explicable by the small amounts taken for laboratory studies, since these did not exceed $15 \mathrm{ml}$. per week during the period of investigation.

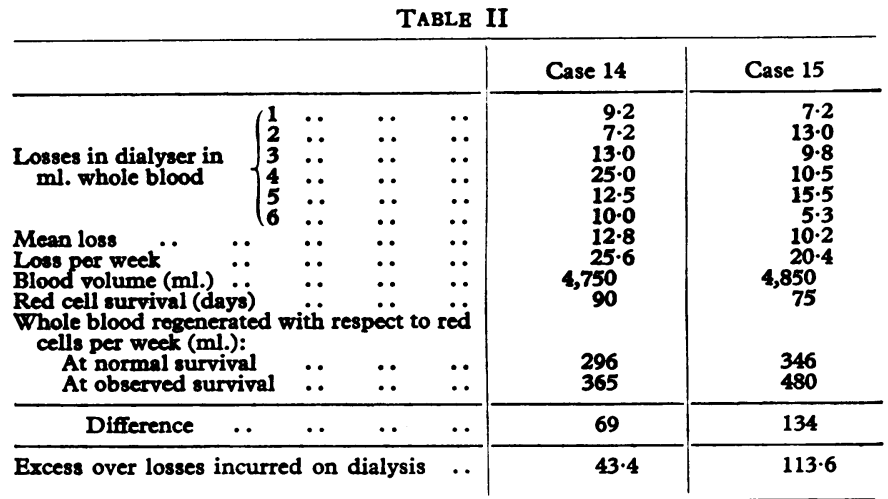

\section{Discussion}

This study confirms the validity of using haematocrit values as a guide to red cell mass in patients on maintenance dialysis, despite the possibility that plasma volume may change according to variations in the state of hydration. A mild haemolytic element is present in most of these patients (Joske et al., 1956 ; Eschbach et al., 1967), and is in addition to the inevitable blood loss at the end of each dialysis. With the newer pattern of Kiil dialyser this loss is very small, being considerably less than the values observed by Lawson et al. (1969), who used comparable techniques with coil dialysers.

The changes in iron transport after dialysis therapy has been started may explain the discrepancy between the data of Eschbach et al. (1967) and those of Kurtides et al. (1964). The latter found that erythropoietic activity increased as a direct result of a single haemodialysis in previously undialysed patients, whereas Eschbach's group could find no consistent effect in patients who had already been maintained on dialysis for varying but appreciable periods. Even so, several of their patients did show an increase in erythrocyte iron turnover over periods of 10 to 35 months.

In this study we have not measured plasma erythropoietin levels. Previous workers have found reduced or zero levels of erythropoietin in the plasma of patients with renal failure, though the Seattle workers (Eschbach et al., 1967) found raised levels in two patients. It has been suggested, therefore, that there may be extrarenal sites of erythropoietin production (Hampers and Schupak, 1967 ; Mirand et al., 1968). Our findings are consistent with the absence of significant erythropoietin production in most patients in this series. It is noteworthy that in only two patients with polycystic disease (in whom there is probably significant residual functioning renal tissue) did parenteral iron raise haemoglobin to nearly normal levels.

The initial stimulus to increased plasma iron transport, which occurs at the beginning of dialysis, is most probably the partial correction of the biochemical abnormalities inhibiting marrow activity, thus permitting increased erythropoiesis. Later there may be loss, by dialysis, of substances necessary for adequate erythropoiesis, leading to deficiency effects (MacKenzie et al., 1969). In our patients folic acid deficiency was excluded and deficiency of other factors was not evident. Thus it is not clear why iron transport should revert to pretreatment levels after this initial increase. Biochemical control tends to be better after a few weeks of dialysis therapy than at the outset, and one might expect the higher level of transport to be maintained.

We have also found that the haemoglobin level often rises under these circumstances, though it still remains subnormal. This higher level of haemoglobin is maintained in patients who 
have not received haematinics. It may therefore be that the apparently transient nature of this increment in useful iron transport is artifactual. One possible explanation is that transport of iron to the liver (observed by Eschbach et al., 1967) may be present in uraemic patients, and may be replaced by the normal physiological transport to the bone marrow after therapy is established. Another explanation may be that ineffective erythropoiesis occurs in these patients before dialysis is begun. Further studies will be needed to investigate these hypotheses. In either instance the utilization of iron transported will be improved, and increased erythropoiesis can be maintained on the same level of transport.

Several authors have drawn attention to the development of iron deficiency in patients receiving maintenance dialysis without transfusion (Crockett et al., 1968 ; Wright et al., 1969) and have indicated the need for iron therapy, often over prolonged periods. Curtis et al. (1969), however, have cautioned that parenteral therapy may lead to hepatic haemosiderosis and have therefore cast doubt on how far iron deficiency is responsible for the anaemia in these patients. These workers found an increase of iron granules in the bone marrow of most of their patients and a fairly high saturation of the iron-binding capacity of the plasma. Many of their patients had received regular blood transfusions until 1966, since when they were given blood only when symptoms of anaemia became distressing. Oral iron produced no improvement in haemoglobin level, and the anaemia in their patients, as in ours, was normochromic. In our patients the saturation of the iron-binding capacity was appreciably lower than in theirs, and oral iron was found to be inconsistent in its effects. Transfusion was an exceptional event in these patients from the outset of their maintenance dialysis, and parenteral iron resulted in partial amelioration of the anaemia in most of those studied.

Our policy was to administer parenteral iron only until serum iron was raised to normal levels and no further rise in haemoglobin resulted. A fall in serum iron and a reversion of haemoglobin to pretreatment levels occurred after discontinuing iron therapy. We have found plasma iron transport to be increased in dialysed uraemic patients when the serum iron is raised by therapy, and studies with ${ }^{59} \mathrm{Fe}$ have shown that this therapeutic iron is well utilized in haemoglobin formation. Useless and potentially harmful accumulation in the liver, however, has not been found.

The enhancement of iron utilization achieved when the serum iron level in our patients was raised remains unexplained, but suggests the possibility of inhibition of iron utilization in the developing erythron, which can be overcome only by increasing the concentration of available iron. With increased saturation of transferrin more of the "erythron-orientated" binding sites will be occupied, and the transfer of iron to the developing red cell thereby facilitated (Fletcher and Huehns, 1968). Sideroblasts are not a feature of uraemic bone marrow. This fact would suggest that if there is a defect it is one of transfer of iron to the developing erythron rather than one of incorporation of iron into the haem molecule. The finding of increased iron granules in the marrow (Curtis et al., 1969) suggests the administration of iron beyond a certain level of transferrin saturation will increase the non-erythroid iron utilization, with the diversion of iron into a less available storage form. Patients who have received few blood transfusions may have true iron deficiency. We agree with Curtis et al. that parenteral iron should be given to maintenance dialysis patients with caution, but we think that it definitely improves erythropoiesis even when iron deficiency, as usually defined, cannot be found, and certainly prevents the development of such deficiency from a combination of restricted diet and dialyser blood loss.

The ${ }^{2} \mathrm{Fe}$ used in this study was prepared in the Medical Research Council Cyclotron Unit at the Hammersmith Hospital, London, and we would like to record our thanks to the Council, and particularly to the Director of the unit, Dr. D. D. Vonberg, and to Dr. J. Silvester for their help and encouragement in this study. We are grateful to the Birmingham Regional Hospital Board for a grant towards part of the cost of this study. We are also grateful to the patients who gave up their spare time to help so willingly in this work, and to Mr. P. Ravel for valuable technical assistance.

\section{Appendix}

\section{Studies with ${ }^{52} \mathbf{F e}$}

This isotope, which has a half-life of 8.2 hours, decays via ${ }^{52 \mathrm{~m}} \mathrm{Mn}$ (half-life 20 minutes). It was shown by Maynard and Fink (1956) that intravenous manganese is rapidly cleared from the plasma (within a few minutes of injection), and this was confirmed for ${ }^{52 m} \mathrm{Mn}$ by Anger and Van Dyke (1964). By making use of the special circumstances of these patients, we have also been able to confirm these observations directly.

A 3-feet $(91-\mathrm{cm}$.) length of sterile plastic tubing was inserted into the arteriovenous shunt of two patients, and this was coiled four times round a 2 -in. $(5-\mathrm{cm}$.) scintillation crystal to give a continuous flow counter. This was coupled to a chartrecording rate meter. The ${ }^{52} \mathrm{Fe}$ was injected on the venous side of the detector and a continuous record of activity obtained over the first five minutes after injection. With the use of pulse height analysis it was possible to minimize detection of ${ }^{52} \mathrm{Fe}$ while recording ${ }^{52 \mathrm{~m}} \mathrm{Mn}$. A multicomponent exponential curve was obtained, which agreed closely with the findings of Maynard and Fink. It is therefore necessary to allow the ${ }^{52} \mathrm{Fe}$ in blood withdrawn from the patient to return to equilibrium with its daughter isotope before it can be compared with the in-vitro standard in which no physical separation of $\mathrm{Mn}$ and Fe has taken place, unless recourse is had to complex counting procedures using more than one channel. Fortunately five half-lives-that is, 100 minutes for ${ }^{52 m} \mathrm{Mn}$-suffices to ensure this.

\section{Studies with ${ }^{86} \mathbf{R b}$}

Preliminary studies showed that uptake of $\mathrm{Rb}$ was greater when blood had been taken into the acid citrate dextrose than when heparin was used as anticoagulant. Uptake depended on the volumes of cells and fluid present and on time of incubation, as well as temperature and agitation of the samples. Conditions were controlled with respect to the last two and the volume of fluid added, so that the uptake could be predicted for a given time and volume of cells. It was usually about $40 \%$.

The rate of elution of the label from the cells in vivo was found to be such that no significant difference was recorded in two patients between samples taken at 10,20, and 30 minutes; and thereafter, to minimize the amount of blood taken from the patients, only a single 10- to 15-minute sample was withdrawn. No detectable ${ }^{86} \mathrm{Rb}$ could be found in the blood of patients three weeks after a study. These findings are in agreement with the values for biological half-life of ${ }^{42} \mathrm{~K}$ and ${ }^{86} \mathrm{Rb}$ of 36 to 40 hours recorded by Yalow and Berson. (1951) and Tudhope and Wilson (1956). Thus the rubidium ion must be efficiently removed by haemodialysis.

\section{REPERENCES}

Anger, H. O., and Van Dyke, D. C. (1964). Science, 144, 1587. Chodos, R. B. (1956). Clinical Research Proceedings, 4, 141. Crockett, ${ }^{2}$. E., et al. (1968). In Dialysis and Renal Transplantation. Proceedings of the 4th Conference of the European Dialysis and Transplant Association, edited by D. N. S. Kerr, p. 17. Amsterdam, Excerpta Medica.

Curtis, J. R., et al. (1969). Quarterly fournal of Medicine, 38, 49. Emerson, C.' P., und Burrows, B. A. (1949). fournal of Clinical Investigation, 28, 779 .

Eschbach, J. W., Funk, D., Adamson, J., Kuhn, I., Scribner, B. H., and Finch, C. A. (1967). New England fournal of Medicine, 276, 653. Fletcher, J., and Huehns, B. R. (1968). Nature, 218, 1211. Hampers, C. L., and Schupak, E. (1967). Long Term Hemodialysis. Joske, R. A., McAlister, J. M., and Prankerd, T. A. J. (1956). Clinical
Science, 15, 511. 
Kurtides, E. S., Rambach, W. A., Alt, H. L., and Del Greco, F. (1964). fournal of Laboratory and Clinical Medicine, 63, 469.

Lajtha, L. G. (1961). The Use of Isotopes in Haematology. Oxford, Blackwell Scientific Publications.

Lawson, D. H., Will, G., Boddy, K., and Linton, A. L. (1969). In Dialysis and Renal Transplantation: Proceedings of the 5 th ConDerence of the European Dialysis and Transplant Association, edited
forition by D. N. S. Kerr, p. 167. Amsterdam, Excerpta Medica.

MacKenzie, J. C., Ford, J. E., Waters, A. H., Harding, N., Cattell, W. R., and Anderson, B. B. (1969). In Dialysis and Renal Transplantation: Proceedings of the 5th Conference of the European Dialysis and Transplant Association, edited by D. N. S. Kerr, p. 172. Amsterdam, Excerpta Medica.
Mann, D. L., Donati, R. M., and Gallagher, N. I. (1965). Fournal of the American Medical Association, 194, 1321

Maynard, L. S., and Fink, S. (1956). Journal of Clinical Investigation, 35, 831 .

Mirand, E. A., Murphy, G. P., Steeves, R. A., Weber, H. W., and Retief, F. P. (1968). Acta Haematologica, 39, 359

Tudhope, G. R., and Wilson, G. M. (1956). British fournal of Haemato-

logy, 2, 75.
Wright, F. K., Goldsmith, H. J., and Hall, S. M. (1969). In Dialysis and Renal Transplantation:" Proceedings of the 5 th Conference of the European Dialysis and Transplant Association, edited by D. N. S. Kerr, p. 179. Amsterdam, Excerpta Medica.

Yalow, R. S., and Berson, S. A. (1951). Science, 114, 14.

\title{
Neurological Disease after Partial Gastrectomy
}

\author{
J. ALEXANDER WILliAMS, *\| CH.M., F.R.c.s. ; G. S. HALL, † M.D., F.R.C.P. ; A. G. THOMPSON, $\ddagger$ M.B., CH.B. \\ W. T. COOKE,§ M.D., F.R.C.P.
}

British Medical fournal, 1969, 3, 210-212

Summary : Clinical and laboratory signs of neurological $\checkmark$ disease were found in 14 patients many years after partial gastrectomy. Vitamin $B_{12}$ deficiency occurred in most patients, but only those three who had signs of subacute combined degeneration of the cord and no osteomalacia responded well to treatment.

\section{Introduction}

There have been relatively few reports of serious neurological disease as a complication of partial gastrectomy. The first description of "subacute combined degeneration of the cord" following a Billroth II partial gastrectomy was recorded by

* Consultant Surgeon.

+ Formerly Consultant Neurologist.

Formerly House-surgeon.

Consultant Physician.

The General Hospital, Birmingham 4.

II In receipt of a grant from the Medical Research Council.
Knox and Delamore (1960), and since then there have been fewer than 10 other cases reported. Nevertheless, Olivarious and Roos (1965) suggested that such neurological complications are much more common; from a variety of Scandinavian sources they were able to review 26 cases of "myelopathy" associated with low serum vitamin- $B_{12}$ levels after gastrectomy. In these patients the average time of onset of neurological symptoms was more than 10 years after operation.

\section{Present Series}

In a five-year period in our centre we have seen and treated 14 patients with neurological disease after partial gastrectomy. In many of these the response to treatment has been poor and some are permanently incapacitated with an irreversible neurological disorder. (Although relatively rare this is obviously an important clinical problem.) The findings in these patients are summarized in Table $\mathrm{I}$.

\begin{tabular}{|c|c|c|c|c|c|c|c|c|c|c|c|c|c|c|c|c|c|}
\hline & & Case & No.: & 1 & 2 & 3 & 4 & 5 & 6 & 7 & 8 & 9 & 10 & 11 & 12 & 13 & 14 \\
\hline $\begin{array}{l}\text { Sex } . . \\
\text { Age (years) } \\
\text { Ulcer site ... } \\
\text { Operation } \\
\text { Time interval (year }\end{array}$ & $\begin{array}{c}. . \\
\dddot{0} \\
\text { ars) }\end{array}$ & $\begin{array}{l}\because \\
\because: \\
\because .\end{array}$ & $\begin{array}{l}\because \\
\because \\
\because \\
\because\end{array}$ & $\begin{array}{l}\text { F } \\
51 \\
\text { G } \\
\text { BII } \\
14\end{array}$ & $\begin{array}{l}M \\
55 \\
D \\
\text { BII } \\
5\end{array}$ & $\begin{array}{l}\text { M } \\
50 \\
D \\
\text { BII } \\
5\end{array}$ & $\begin{array}{l}\text { M } \\
57 \\
\text { G } \\
\text { BII } \\
12\end{array}$ & $\begin{array}{l}M \\
56 \\
D \\
\text { BII } \\
16\end{array}$ & $\begin{array}{l}M \\
63 \\
\mathrm{G} \\
\mathrm{BII} \\
10\end{array}$ & $\begin{array}{l}M \\
63 \\
\text { G } \\
\text { BII } \\
10\end{array}$ & $\begin{array}{l}\mathrm{F} \\
68 \\
\mathrm{G} \\
\mathrm{BI} \\
12\end{array}$ & $\begin{array}{l}M \\
68 \\
\text { G } \\
\text { BII } \\
14\end{array}$ & $\begin{array}{c}F \\
76 \\
G \\
G . E . \\
37\end{array}$ & $\begin{array}{l}\text { F } \\
54 \\
\text { G } \\
\text { BII } \\
11\end{array}$ & $\begin{array}{l}M \\
67 \\
\text { D } \\
\text { BII } \\
12\end{array}$ & $\begin{array}{l}M \\
41 \\
G \\
\text { BII } \\
14\end{array}$ & $\begin{array}{l}\mathrm{M} \\
55 \\
\mathrm{D} \\
\mathrm{BII} \\
13\end{array}$ \\
\hline $\begin{array}{l}\text { Symptoms: } \\
\text { Unsteadiness } \\
\text { Weakness } \\
\text { Paraesthesia } \\
\text { Numbness } \\
\text { Depression or ps } \\
\text { Loss of consciou }\end{array}$ & $\begin{array}{l}. . \\
\because \\
\because \\
\text { psychos } \\
\text { usness }\end{array}$ & $\begin{array}{l}. . \\
\ddot{0} \\
\text { sis } \\
\ddot{.}\end{array}$ & $\begin{array}{l}\because \\
\because \\
\because \\
\because\end{array}$ & $\begin{array}{l}+ \\
+ \\
+ \\
+ \\
+ \\
+\end{array}$ & $\begin{array}{l}+ \\
+ \\
+ \\
+ \\
+ \\
+\end{array}$ & $\begin{array}{l}+ \\
+ \\
+ \\
+ \\
+ \\
+\end{array}$ & $\begin{array}{l}+ \\
+ \\
+ \\
+ \\
+ \\
+\end{array}$ & $\begin{array}{l}+ \\
+ \\
+ \\
+ \\
+ \\
+\end{array}$ & $\begin{array}{l}+ \\
+ \\
+ \\
+ \\
+ \\
+\end{array}$ & $\begin{array}{l}+ \\
+ \\
+ \\
+ \\
+\end{array}$ & $\begin{array}{l}+ \\
+ \\
+ \\
+ \\
+\end{array}$ & $\begin{array}{l}+ \\
+ \\
+ \\
+ \\
+\end{array}$ & $\begin{array}{l}+ \\
\pm \\
+ \\
+\end{array}$ & $\begin{array}{l}+ \\
+ \\
+ \\
+ \\
+\end{array}$ & $\begin{array}{l}+ \\
+ \\
+ \\
+ \\
-\end{array}$ & $\begin{array}{l}+ \\
+ \\
\pm \\
\pm \\
=\end{array}$ & $\begin{array}{l}+ \\
\pm \\
\overline{+} \\
+\end{array}$ \\
\hline $\begin{array}{l}\text { Signs: } \\
\text { Wasting in legs } \\
\text { Hypotonia } \\
\text { Plantar response } \\
\text { Loss of position } \\
\text { Loss of vibratior } \\
\text { Loss of pin-pric }\end{array}$ & $\begin{array}{l}\text { e } \\
\text { n sense } \\
\text { on sens } \\
\text { ck sens }\end{array}$ & $\begin{array}{l}. . \\
\because \\
\text { se } \\
\text { sation }\end{array}$ & $\begin{array}{l}\because \\
\because \\
\because \\
\because \\
.\end{array}$ & $\begin{array}{l}\overline{-} \\
\overline{\mathrm{FI}} \\
+ \\
\pm \\
\pm\end{array}$ & $\begin{array}{l}+ \\
\mathbf{E x} \\
+ \\
+ \\
+\end{array}$ & $\begin{array}{l}+ \\
+ \\
\mathbf{E x} \\
+ \\
+ \\
+\end{array}$ & $\begin{array}{l}+ \\
+ \\
\text { Fl } \\
+ \\
+\end{array}$ & $\begin{array}{l}+ \\
+ \\
\mathrm{F} 1 \\
+ \\
+ \\
+\end{array}$ & $\begin{array}{l}+ \\
\\
\text { Ex } \\
+ \\
+ \\
+\end{array}$ & $\begin{array}{l}+ \\
\pm \\
\text { Ex } \\
\pm \\
\pm\end{array}$ & $\begin{array}{l} \pm \\
\mathrm{Fl} \\
+ \\
+ \\
-\end{array}$ & $\begin{array}{l}+ \\
+ \\
\text { F1 } \\
- \\
+ \\
-\end{array}$ & $\begin{array}{l}+ \\
+ \\
\text { F1 } \\
+ \\
+ \\
+\end{array}$ & $\begin{array}{l}\overline{-} \\
\bar{F} 1 \\
\overline{+} \\
-\end{array}$ & $\begin{array}{l}- \\
\overline{E x} \\
+ \\
\pm \\
-\end{array}$ & $\begin{array}{l}- \\
+ \\
\text { Ex } \\
+ \\
+ \\
+\end{array}$ & $\begin{array}{l}+ \\
+ \\
\text { F1 } \\
+ \\
+ \\
+\end{array}$ \\
\hline $\begin{array}{l}\text { Associated deficien } \\
\text { Weight loss } \\
\text { Poor diet } \\
\text { Alcoholism } \\
\text { B12 deficiency } \\
\text { Iron deficiency } \\
\text { Osteomalacia } \\
\text { Steatorrhoea }\end{array}$ & $\begin{array}{l}\text { ncies: } \\
\because \\
\because \\
\because \\
\because \\
\because \\
\cdots\end{array}$ & $\begin{array}{l}\because . \\
\because . \\
\because . \\
\because .\end{array}$ & $\begin{array}{l}\ldots \\
\because . \\
\because . \\
\because .\end{array}$ & $\begin{array}{l}+ \\
- \\
+ \\
+ \\
+ \\
+ \\
+\end{array}$ & $\begin{array}{l}+ \\
\pm \\
+ \\
+ \\
+ \\
+\end{array}$ & $\begin{array}{l}\overline{+} \\
+ \\
+ \\
+ \\
+ \\
+\end{array}$ & $\begin{array}{l}+ \\
\overline{-} \\
+ \\
+ \\
+ \\
+\end{array}$ & $\begin{array}{l} \pm \\
\overline{+} \\
\pm \\
\pm \\
+\end{array}$ & $\begin{array}{l} \pm \\
\overline{+} \\
\pm \\
+\end{array}$ & $\begin{array}{l}+ \\
\pm \\
\pm \\
\pm \\
\pm \\
+\end{array}$ & $\begin{array}{l}\overline{+} \\
\pm \\
\overline{+} \\
\pm \\
+\end{array}$ & $\begin{array}{l}+ \\
+ \\
+ \\
+ \\
+ \\
+ \\
+\end{array}$ & $\begin{array}{l}+ \\
\pm \\
+ \\
+ \\
+ \\
+\end{array}$ & $\begin{array}{l}+ \\
\pm \\
\pm \\
+ \\
\pm \\
+\end{array}$ & $\begin{array}{l}= \\
\overline{-} \\
+ \\
+ \\
+ \\
+\end{array}$ & $\begin{array}{l}+ \\
\pm \\
+ \\
+ \\
+ \\
+\end{array}$ & $\begin{array}{l}+ \\
+ \\
+ \\
+ \\
+ \\
+ \\
+\end{array}$ \\
\hline
\end{tabular}

